\title{
Shabbat as a projection of freedom in Tanakh and rabinic Judaism
}

\section{[Sabat jako projekce svobody v Tanachu a rabinskem judaismu]}

\author{
Marie Roubalova - Patrik Maturkanic - Janka Bursova - Peter Kondrla \\ - Jan Zimny
}

DOI: 10.18355/XL.2022.15.01.15

\begin{abstract}
The study presents the concept of religious freedom in Judaism. It examines the Shabbat day as a consecrated day. The principle of this day is to celebrate the Lord, to experience joy, to refrain from both work and activities that are not allowed. The basic vision of freedom is to limit the influence of earthly worries, interests, and to move closer toward the Lord and the needs that are rooted in the spiritual nature of man. The study of examples from the text shows a different approach to understanding freedom from a philosophical and religious point of view. It presents the ways in which the reduction of human terrestrial orientation is achieved, including the prohibition of the mitzvah. It distinguishes between the partial goals of human existence and its ultimate goal in reaching the Lord. Restriction of freedom is interpreted as a restriction in achieving partial goals, which creates space for orientation to the last determination of man. The repetition of the Sabbat is presented as a didactic means of permanently directing man towards the final goal, which at the same time gives meaning to the existence of man as a whole being.
\end{abstract}

Key words: freedom, Shabbat, restriction of freedom, last goal, Judaism, Tanakh

\begin{abstract}
Abstrakt
Studie představuje koncept náboženské svobody v judaizmu. Zkoumá svátek šabatu jako zasvěceného dne. Principem tohoto dne je oslava Hospodina, proživaní radosti, zdržení se práce a činností, které nejsou povoleny. Základní vize svobody spočívá vomezení vplyvu pozemských starostí, zájmů a nasměrovaní k Hospodinu a potřebám, které jsou ukotvené v duchovní podstatě člověka. Studie na př́kladech $\mathrm{z}$ textu ukazuje rozdílný př́stup $\mathrm{v}$ chápání svobody z filosofického a náboženského pohledu. Prezentuje způsoby, kterými je dosahováno omezování pozemské orientace člověka, včetně zákazu micva. Rozlišuje mezi částkovými cíli existence člověka a jeho posledním cílem v Hospodinu. Omezení svobody je interpretováno jako omezení v dosahování parciálních cílů, čím se vytvárí prostor pro orientaci k poslednímu určení člověka. Opakováni šabatu je prezentováno jako didaktický prostředek permanentního směřování člověka k poslednímu cíli, který zároveň dává smysl existenci člověka jako celku bytí.
\end{abstract}

Klíčová slova: Svoboda, šabat, omezení svobody, poslední cíl, judaizmus, tanach

\section{Úvod}

„Šabat je nejjasnějši vyjádřeni těch zákonů, kterými člověk žije, které hlásaji životu prátelského ducha Tóry a jsou tak odlišné od magie a pověr, jako je Bủh Tanachu odlišný od závistivého skřitka. " (Weiner, 1967: 72)

Filosofický koncept svobody v sobě integruje různé interpretace. Nejobecnější je chápaní svobody jako nepřítomnosti omezení volby a konání. (Sacks 2013: 29-31). Liberální pojetí svobody stanovuje hranici svobody, která je definována svobodou jiného. Svoboda druhého člověka je neredukovatelná a není možné ji omezit. Takové chápaní svobody, charakteristické i pro současné myšlení, nedokáže akceptovat náboženskou interpretaci svobody, ve které je implikován rozměr poslušnosti a 
zachovávaní přikázaní. (Právě z této interpretace svobody vznikají i omyly ve filosofických interpretacích náboženství. (Zalec, Pavlikova 2019).

Letmý pohled do židovského světa $\mathrm{z}$ vnějšku zpravidla přináší několik zásadních omylů. Prvním je představa, že vyvolenost Božího lidu je jistý druh protekce. Druhým je domněnka, že sobotní zákony jsou téměř nesnesitelným jhem, které Bůh vložil na bedra svého lidu. Ve skutečnosti je tomu právě naopak. Tvrdé jho, vložené na Izrael, je jeho vyvolenost. Sobotní př́ḱkazy a zákazy oproti tomu nejsou neprŕíjemnou komplikací, nýbrž velkou radostí a požitkem, které si neumí představit ten, kdo je nikdy neprožil. To potvrzují i slova chasidského rabína Jicchaka Jaakova, který řekl: „Bylo by téměr nemožné porušit sobotni zákony, kdyby měl člověk ruce a nohy svázané, ale nepřineslo by to žádný užitek, protože by to zabránilo požitku ze šabatu." (Lubliner 2020) Třetím běžným omylem je představa, že to jsou Židé, kdo zachovávají sobotu. Ve skutečnosti je tomu přesně naopak, je to právě zachovávání šabatu, které umožnilo zachování židovského národa, jak řekl Ahad HaAm (18561927): „Nakolik Židé zachovávali sobotu, natolik sobota zachovala židovský národ. “(Kaplan 1991)

Sobota je Bohem požehnaný a posvěcený den, který vyžaduje úctu (hebr. „kavod“) a přináší radost (hebr.: „simcha“) a potěšení (hebr.: „oneg“). Šabat je tak nejvýznamnější, nejposvátnější a nejčastěji se opakující židovská slavnost. Její dodržování má podle rabínů větší význam než dodržování půstu a stejný význam jako plnění všech ostatních přikázání Tóry. (Aruch hašulchan, Orach chajim 60,3 „Dodržovat šabat je totéž jako dodržovat celou Tóru“", (Nedarim 3,14; Midraš raba, Šemot 25,12; Zohar, Bešalach 47; Kicur šulchan aruch 72,1) protože ,znamená tolik, co všechny ostatní přikazy“ (JT, Nedarim 3; Kicur šulchan aruch 72,1). „Dodržet šabat je víc než dodržet tisíc dnů postu. " (Midraš Tanchuma, Berešit).

Mnohá z ustanovení Tóry platí pouze v Izraeli, oproti tomu šabat se musí dodržovat všude (musel být dodržován např́íklad již na poušti cestou do zaslíbené země). (Třetí kniha Mojžíšova (dále jen Vajikra) 23,21; Chizkuni, Bemidbar 15,32) Jak ukazuje případ lidí, kteří první sobotní den na poušti vyšli sbírat manu (Šemot 16,27) a př́pad muže, který na poušti druhou sobotu sbíral dřevo (Bemidbar 15,32-36) a byl za to př́ísně potrestán (viz níže).

Proč byl ten muž potrestán, když sbíral dřevo pro svou vlastní potřebu? Jsou nařízení Boží tak nesmyslná, že nedovolí člověku postarat se o svůj vlastní život a zabezpečit uspokojení svých základních existenčních potřeb? Má člověk raději zemřít, než by se protivil zákonu? Tyto a jiné otázky vyvstávají z povrchní filosofické interpretace svobody věřícího člověka a v podstatě se míjí záměrem Tóry. Jak ukážeme v dalších částech této studie, člověk je povolán k dokonalosti a dokonalosti dosahuje pomocí zachovávání řádu. Bůh určuje, kdy je třeba pracovat a kdy se modlit, kdy je třeba hodovat a kdy se postit. Není to jeho svévole, ale záměr, který je pro dobro člověka. Bůh vidí člověka ze své transcendentní pozice a vidí, co člověk potřebuje, chrání člověka před sebou samým, tj. před vlastní svobodou. Problematice svobody se věnoval ve svých spisech Nemoc $k$ smrti, Bázeň a chvění (ve spojení s Abrahámem) dánský myslitel Søren Kierkegaard (1813-1855). Recepce Kierkegaarda jsou přehledně zpracovány ve studiích Romana Králika (Kralik, 2013; Kralik, Pavlikova, 2013; Kralik, 2016).

\section{Požehnaný a svatý šabat}

Na první pohled se jeví trest za ignorování šabatu jako tvrdý a nepřiměřený. Jistě, pro věŕícího Žida je nepřípustné protivit se vůli Boží. Je však nevyhnutné, aby neuposlechnutí bylo trestáno smrtí? To může vypadat jako nesvoboda. Na druhé straně je však nutno si uvědomit, že respektování Hospodinova příkazu má silný racionální kontext. Hospodinovy př́íkazy mají, kromě jiného, významný pedagogický rozměr. Vedou vyvolený lid a učí ho, jak a co má dělat. Ve čtvrtém přikázání (o

XLinguae, Volume 15 Issue 1, January 2022, ISSN 1337-8384, eISSN 2453-711X 
šabatu) je zpřítomněna historická zkušenost, ve které člověk zapomíná na oddych, svou mysl bez přestání orientuje $\mathrm{k}$ práci, $\mathrm{k}$ problémům a nezůstává mu prostor pro uvědomení si vlastní existence a její propojení s Bohem. Proto je šabat něco jako tabu, něco, co není možno porušit a ignorovat. Ignorovaní šabatu je ignorovaní duchovního rozměru vlastní existence, která je existencí s Bohem.

Samotný charakter šabatu však nemá jen negativní podobu zákazu konání. Naopak je to den, ve kterém člověk naplňuje své existenční poslání tím, že vše časné odkládá a svoji mysl a své konání orientuje směrem k Hospodinu. Je to den požehnání. Podle úvodního hymnu Tóry Bůh při stvoření sobotě nejen požehnal (,vajvarech“) obdobně jako požehnal člověku (Berešit 2,3) a zvířatům (Berešit 1,28), ale také jej posvětil („vajkadeš“). Obojí poukazuje na výjimečnost tohoto dne. Šabat je tak představen jako vrchol všeho stvoření. Dokonce člověk, který obvykle chápe jako vrchol stvoření sám sebe, je tímto vrcholem pouze $\mathrm{v}$ kontextu sobotního dne, který tráví se svým Bohem.

Bůh při stvoření světa požehnal jedinému ze sedmi dnů - šabatu (Berešit 2,3). Rabíny zneklidňovalo, proč to udělal a v čem toto požehnání spočívalo. Rabi Berechija se domníval, že Bůh dal sobotě požehnání jako dar, aby jí nebylo líto, že jako jediný den v týdnu nemá svého partnera. Neděle (den první) má pondělí (den druhý), úterý (den třetí) má středu (den čtvrtý) atd. Podle jiného názoru první den (kdy bylo stvořeno světlo) má čtvrtý den (kdy byla stvořena světla), druhý den (voda) má pátý den (ryby a ptáci), třetí den (souš) má šestý den (suchozemská stvoření). Rabi Šemuel ben Natan se oproti tomu domníval, že Bůh požehnal tento den, protože jej nelze odložit na jiný den obdobně jako Jom kipur (Berešit raba 11,8). Podle jiných rabínů spočívalo požehnání soboty ve dvojí porci many (nebeský pokrm) (RAŠBAM, Šemot 16,15), která padala před šabatem $z$ nebe pro Izrael na poušti. (RAŠI, Šemot 20,11; RAŠBAM, Šemot 20,11; Berešit raba 2,2; Mechilta derabi Jišmael 20.11.3; Kedušat Levi, Šemot 32) Seslání many bylo podle rabínské tradice spojeno s třemi zázraky, které učí člověka tři důležité věci: (1) V sobotu nepadala žádná mana (tj. samo nebe zachovává šabat), protože její sběr by porušil svatost soboty, aby se všichni naučili, že je nezbytné světit šabat. (2) Vždy padalo dostatečné množství many, aby se všichni naučili, že je zbytečné hromadit nadbytečné zásoby. (3) V pátek padalo dvojnásobné množství many, aby se všichni naučili, že je nezbytné připravit se na šabat. (Akedat Jicchak 41.1.7) Podle Ibn Ezry sedmý den Bůh požehnal tím, když umožnil, aby lidské tělo mohlo o šabatu hostit ještě jednu (sobotní) duši a tím v sobotu zvýšil duchovní kapacitu člověka. (Tur haaruch, Šemot 20,11)

Šabat je jedním z pilírů judaizmu, připomínaný již v biblickém prríběhu o stvoření světa a je zmíněný i v Desateru. Šabat je v Tóře označovaný za znamení smlouvy mezi Bohem a lidem Izraele. Šabatovým předpisům se více věnuje stejnojmenný traktát v Talmudu. Vědomé znesvěcení šabatu (CHILUL ŠABAT) odpovídá v rabínské tradici modloslužbě (Divecký, 2005: 73-74).

Svatost šabatu je přikázána Tórou: „Pamatuj na den odpočinku, že ti má být svaty" (Šemot 21,12; 31,14) Sám Bůh nazývá sobotu: „můj svatý den“ (Ješajahu $58,13)$. Sobota je svatá, jako je svatý Bůh a jeho jméno. Bůh si šabat oddělil pro sebe jako svatý a zároveň jej dal člověku jako zvláštní oddělený čas. (Berešit 2,1-3; Šemot 16,29; 20,11; Jechezkel 20,12) Podle Talmudu při tom stanovil: ,Vy nejste pro sobotu, sobota je pro vás" (BT, Joma 85b; srv. Mechilta 31,11). Sobota si podle rabínů po stvoření světa stěžovala, že každý den v týdnu má svého partnera (viz výše). Pouze ona žádného společníka nemá. Bůh proto stanovil, že pospolitost Izraele bude společníkem šabatu. Také z tohoto důvodu musí být pospolitost Izraele svatá. Další otázkou je otázka svědomí jednotlivého člověka. (Binetti, Pavlíková 2019).

Podle rabínů je povinné (RAMBAM, Mišne Tora, Hilchot avodat kochavim 12,3) verbálně vyjádřit svatost soboty nad vínem (BT, Pesachim $110 \mathrm{a} ; 108 \mathrm{~b}$ ) recitací modlitby „kiduš“ (posvěcení) při př́íchodu šabatu a recitací „havdaly“ (oddělení svatého šabatu od všedních dnů) (RAMBAM, Mišne Tóra, Hilchot šabat 29,1; 
RAMBAM, Sefer hamicvot, Ase 155,1; Sefer hachinuch, Micva 31,1) při odchodu šabatu (BT, Berachot 52a). Svatost soboty zvětšuje zapálení sobotních světel bezprostředně před jejím příchodem v pátek večer. (RAMBAM, Mišne Tóra, Hilchot šabat 30,5) Tímto způsobem je totiž oddělen kousek všedního dne a je přidán ke svaté sobotě, jejíž svatost je o tento malý kousek zvětšena.

\section{2 Úctyhodný šabat}

Šabat zpř́itomňuje Boha. Podle Šimona bar Jochaje je šabat dokonce jedno z Božích jmen. (Zohar II,88b; 128a) Zachovávání či nezachovávání šabatu ukazuje, zda člověk Hospodinu důvěřuje nebo nedůvěřuje. Aruch hašulchan 242,3) Porušení soboty je popřením úvodní zvěsti Tóry, která oslavuje Boha stvořitele. (Sforno, Šemot 31,14; srov. BT, Sanhedrin 41a; Sifri 113; BT, Raši, Sanhedrin 41a) Úcta vůči šabatu není podle rabínů požadavkem Tóry, ale je požadavkem Proroků (prorok Ješajahu v 58,13 požaduje: ,a budete jej ctit“"). (RAMBAM, Mišne Tóra, Hilchot šabat 30,1) Výrazem úcty vůči sobotě je (1) příprava domácnosti (včetně úklidu); (2) př́íprava jednotlivce (včetně očisty a slavnostního oděvu) na její prríchod během pátečního dne a (3) nákupy konané na počest šabatu v průběhu celého předchozího týdne. (BT, Šabat 119a; BT, Bejca 16a; Rambam, Mišne Tóra, Hilchot šabat 30,5-6; Šulchan aruch, Orach chajim 250,1; Kicur šulchan aruch 72,5)

Neúcta k sobotě je neúctou vůči Bohu. Projevy neúcty vůči Bohu jsou trestány smrtí. Hrozbou trestem smrti je proto chráněno také dodržování soboty. První př́ípad, kdy byl vynesen trest smrti za znesvěcení soboty je zmíněn v knize Bemidbar: „Když Izraelci prodlévali na poušti, přistihli muže, kterýv den odpočinku sbiral dřiví. Ti, kdo jej pristihli, jak sbirá dřiví, předvedli jej před Mojžíše a Árona a před celou pospolitost. Dali ho střežit, nebot' nebylo zřejmé, co se s ním má stát. Hospodin řekl Mojžíšovi: „,Ten muž musí zemřit. Celá pospolitost jej ukamenuje venku za táborem. Celá pospolitost ho vyvedla ven za tábor a ukamenovali ho, takže zemřel, jak Hospodin Mojžišovi přikázal " (Bemidbar 15,32-36). Porušení soboty je proviněním proti Bohu, ale vykonání trestu Bůh delegoval na pozemský soudní tribunál. (Or hachajim, Šemot 31,14)

Cílem trestu za znesvěcení a znevážení šabatu bylo podle rabínů vytětí duše z vyvoleného lidu. (Šemot 31,12-17; 35,2; Bemidbar 15,35n, RAMBAM, Mišne Tóra, Hilchot šabat 7,1, Šemot 31,14 ) Tento názor vychází z ustanovení knihy Šemot: „Kdo jej znesvětí, musí zemřit. Každý, kdo by v něm dělal nějakou práci, bude vyobcován ze společenstvi svého lidu." (Šemot 31,14) Rabíni toto ustanovení interpretovali jako ustanovení dvou odlišných trestů za porušení soboty, podle způsobu a okolností za kterých k němu došlo. (Mechilta derabi Jišmael, Šemot 31,14; RAŠI, Šemot 31,14)

$\mathrm{K}$ trestu smrti mělo podle názoru rabínů dojít pouze $\mathrm{v}$ případě, že viník porušil šabat úmyslně, byl předem varován a jeho ohavnému jednání byli př́tomni svědci (tj. čin byl spáchán veřejně). (Raši, Šemot 31,14; Rabejnu Bachja, Semot 31,14; Siftej chachamim, Šemot 31,14; RAMBAM, Mišne Tóra, Hilchot šabat 1) Chizkuni se domníval, že muž sbírající dřevo na poušti byl před svou činností varován muži (strážci sobotních zákonů ustanovených Mojžíšem) (Haamek Davar, Bemidbar 15,32), kteří jej při tom přistihli, což zároveň dokládá, že svou činnost vykonával veřejně. Sobotu svým chováním sběrač dřeva porušil třemi rozličnými způsoby: (1) sekal dř́iví takovým způsobem, aby je mohl svázat do otýpky; (2) svázal dřevo do otýpky tak, aby je mohl nosit po poušti; (3) nosil otýpku ve veřejném prostoru (při tažení Izraele pouští šlo o veřejný prostor na rozdíl od běžné situace, kdy poušt' za veřejnou doménu považována není) (RAMBAM, Mišne Tora, Hilchot šabat 14; Or hachajim, Bemidbar 15,32, BT, Šabat 96; Chizkuni, Bemidbar 15,32)

Ten, kdo veřejně tj. v př́itomnosti nejméně deseti mužů (Kicur šulchan aruch 72,2) znesvětil šabat, byl pokládán za odpadlíka od víry v Hospodina, o němž bylo řečeno:

XLinguae, Volume 15 Issue 1, January 2022, ISSN 1337-8384, eISSN 2453-711X 
„Dotkne-li se vína, učini je neprijatelné k požití; chléb jím upečený je považován za chléb modláře..." (Kicur šulchan aruch 72,2) Takový člověk přestal být členem společenství Hospodinových vyznavačů. (Šulchan aruch, Jore dea 2,5; 119,7; Mišna berura 55,46) Jeho usmrcení mělo být vykonáno tím nejbolestnějším ze čtyř trestů smrti - ukamenováním (Bemidbar 15,32-36; Rabejnu Bachja, Bemidbar 15,34; Chizkuni, Šemot 31,13) které zákon umožňoval (vedle upálení, stětí mečem a oběšení). Kdo veřejně znesvětil šabat byl tedy stíhán stejně jako ten, kdo spáchal ty nejtěžší zločiny: znesvětil Boží jméno, zradil Hospodina, víru, svůj národ a odešel sloužit jiným bohům. (Mišna, Sanhedrin 7,4; BT, Sanhedrin 55a) Kdo porušil šabat byl tak roven člověku, který uctíval pohanské modly. (BT, Eruvin 69b; BT, Chulin 5a) Duše takového člověka musí být vyt'ata, musí zemřít. (RAMBAM, Mišne tora. Hilchot tešuva 8,5)

Jak již bylo uvedeno výše, smrt za ignorování šabatu se Tórou nedotčenému a na sebe sama zaměřenému člověku může jevit jako tvrdý trest. Trest je však v pedagogice běžné využíván jako prostředek. Filosofie výchovy pokazuje na to, že trest je simulací důsledku, které se dostaví v případě, že žák odmítá spolupráci a ignoruje proces výchovy a vzdělávání. Trest nepřináší stejné účinky jako reálná porušení př́ikazu $\mathrm{v}$ reálném životě. Když někdo skočí do vysoké pece, tak už je pozdě. Když ale na malém ohni zjistí, jaké reálné nebezpečenství představuje, tak ho malý trest může uchránit před smrtí. Když někdo ignoruje šabat, odmítá Boha. A kdo v komunitě Božího lidu odmítá Boha, musí zemřít. Pokud by zůstal naživu, byl by důkazem, že Bůh netrestá provinění a že člověk si může dělat, co si zamane. To by však znamenalo anarchii a rozpad vyvoleného národa. A zároveň by to znamenalo i dehumanizaci společnosti, která by veškerou svou aktivitu orientovala směrem $\mathrm{k}$ práci, zisku a pozemským starostem či strastím. Byl by to konec národa, konec náboženství a ohrožení civilizace. Filosofické pozadí toho trestu je však těžké vysvětlit jednoduchému člověku, jedinci. Věřící nebude rozumět slovům o historické zkušenosti, o nevyhnutelnosti intelektuálního a duchovního rozvoje osobnosti apod. Rozumí však tomu, že se Bůh zlobí a že toho, kdo neuposlechne, čeká trest.

Rabíni se shodují na tom, že pozemským soudním tribunálem za znesvěcení šabatu „ve skutečnosti nebyl téměr nikdo nikdy usmrcen“. (Mišna, Makot 1,10) Dodržet podmínky stanovené rabíny pro odsouzení pachatele $\mathrm{k}$ trestu smrti bylo $\mathrm{v}$ tomto případě téměř nemožné. Znesvěcení šabatu nerozlišovali pouze na úmyslné a neúmyslné, nýbrž i na „Z počátku úmyslné“ a pak neúmyslné“ nebo „z počátku neúmyslné a pak úmyslné" apod.

Druhým možným trestem v př́ípadě znesvěcení soboty bylo podle rabínů ,vytětí“. Pokud pachatel porušil šabat neúmyslně (z nevědomosti nebo nedopatřením), chyběli svědci jeho činu nebo varovné poučení, měl být provinilec pouze vyhnán ze svého lidu (tím bylo provedeno jeho „vytětí“ z lidu). (Raši, Šemot 31,14; Rabejnu Bachja, Šemot 31,14 ) V době putování lidu Izraele pouští, kdy byl uvedený př́íkaz vydán, se však vyobcování nepochybně rovnalo trestu smrti, protože jednotlivec mohl jen stěží sám přežít $\mathrm{v}$ nehostinných podmínkách pouště.

Podle rabínů by se však nikdo neměl spoléhat na to, že se vyhne trestu smrti, když bude znesvěcovat šabat $\mathrm{v}$ nepř́itomnosti svědků. Trest smrti pro přestupníka totiž není nikdy anulován. Pouze je předán z rukou pozemského soudního tribunálu do rukou nebeského soudního tribunálu. Je „přenechán Bohu, lidská ruka soudce na něj nesměla být vztažena." (Wiener, 1967: 74) Božím soudem mohl být člověk odsouzen k smrti (nemuselo jít o okamžitou smrt, spíše se uvažovalo o předčasné smrti tj. smrti před šedesátým rokem věku) nebo k bezdětnosti, což byla smrt pachatelových potomků, kteří se nenarodí.

\section{Den radosti a potěšení}

Realita je pro člověka hlavně to, s čím má zkušenost. Specificky je to zkušenost, která je nějakým způsobem spojená s emočním prožitkem. Některé filosofické koncepce 
zabývající se teorií poznání př́imo odkazují k emocionalitě jako nevyhnutelnému prvku tvorby a ukládaní zkušenosti se světem. Např. fenomenologie klade důraz na to, jak se svět jeví člověku a ne na to, jaký svět doopravdy je. To, jak se svět jeví člověku, je tvořeno i jeho emocionálním prožíváním. Emoční prožívání zkušenosti se hlouběji vpisuje do paměti, zanechává hlubší pamětovou stopu a v konečném důsledku člověk takové zkušenosti přikládá větší význam než zkušenosti bez emoční stopy. Smrt člověka je svázána se smutkem, narození s radostí. I prožívaní náboženských a liturgických situací je emočně podbarvené. Zřejmě proto, i vzhledem k významu šabatu pro věřícího Žida, bylo nevyhnutelné, aby se s tímto dnem vázala pozitivní emoční konotace. Emocionální prožívání svátečního dne je důkazem skutečného spojení tohoto dne s Bohem. Radost je znakem prŕtomnosti dobra, se kterým se člověk setkává. Pozitivní emoční konotace šabatu se v neposlední řade hlouběji vpisuje do paměti, šabat se stává realitou v mysli věřícího. Je to den reálného střetnutí člověka s Bohem.

Sobota již v době před babylonským exilem nebyla jen dnem bez práce, ale byla radostným svátkem. Tento den je smutek hříchem. (Wistinetzki, 1927: 326) K radosti tohoto dne nepochybně přispívalo také to, že v sobotu lidé navštěvovali muže Boží a svatyně (Hošea 2,13; Melachim bet 4,23; Ješajahu 1,13), docházelo k „rovnáni“" předkladných chlebů, ke střídání stráží v paláci i v chrámu. (Vajikra 24,5-9; Malachim bet 11,5-8) Počet zviŕat obětovaných v sobotu v chrámu se zvyšuje na dvojnásobek (Jechezkel 46,4). Východní brána vnitřního nádvoří, po šest dní uzavřená, se na šabat a novoluní otevírá, brány Jeruzaléma se uzavírají. (Jechezkel 44,24; Nechemja13,19-22) V pozdější době k radosti svátečních dnů přispívala návštěva synagog a rabínů - učitelů Tóry (BT, Roš hašana 16b), protože „,návštěva rabina je srovnatelná s návštěvou šechiny (Boži přitomnosti)“ (BT, Roš hašana 16b). $\mathrm{V}$ rodině tuto radost podporují také tři sváteční jídla. ((BT, Šabat $117 \mathrm{~b})$ Účast na třech hostinách přináší podle Talmudu odpuštění hříchů a záchranu před rozsudkem Gehinom. A právě to, přináší člověku velkou radost. (BT, Šabat $118 \mathrm{a}, \mathrm{b}$ ) Radost je podpořena rovněž tím, že tento den nejsou vyznávány hř́ichy. Lidé nečiní pokání, nepostí se a v modlitbě neprosí o vytržení z úzkosti a trápení. Ve vážných situacích v sobotu Boží vyznavači nepodléhají zármutku, ale snaží se hledat něco pozitivního. Při návštěvě nemocného $\mathrm{v}$ sobotu by se nemělo naříkat a plakat, nemocnému lze říci: „Je šabat. Nesmiš naříkat. Jistě budeš brzy uzdraven.“ (BT, Šabat 12a)

Radost (simcha), která je přikázána ve svátečních dnech (ve dnech jom tov) (Šulchan aruch, Ocar chajim 529,4 a Magen Avraham 529,4) však pro šabat přikázána být nemůže, protože šabat prožívá i truchlící nad mrtvým příbuzným (sedmidenní období „šivy“ vždy zahrnuje jeden šabat). Truchlící nelze nutit k radosti. (BT, Moed katan 23b)

Požitek ze šabatu se nazývá „oneg šabat“ („rozkoš šabatu“, „potěšení ze šabatu“). Toto označení je převzato ze slov proroka Ješajahu: „Nazvě̌-li den odpočinku rozkošným (,oneg“)."( BT, Moed katan 23b) Babylonský talmud používá tento prorocký text jako důkaz závaznosti požadavku potěšení ze šabatu. (BT, Pesachim 68b; srv. RAMBAM, Mišne Tóra, Hilchot šabat 5,1; 30) Podle Rambama je „oneg šabat" požadavkem Proroků nikoliv požadavek Tóry. (RAMBAM, Mišne Tóra, Hilchot šabat 20,1) Někteří rabíni však i „oneg šabat“ považují za prríkaz Tóry („deorajta“) spíše než př́íkaz „divrej kabala“ nebo „divrej derabanan“. (RAMBAN, Vajikra 23,2 - 4. Chatam sofer, Šeelot utešuvot, Orach chajim 168) Výraz „oneg“ (ajin-nun-gimel) bývá vykládán jako akrostich skrývající v sobě odkaz na to nejrozkošnější místo na světě - „Eden“ začínající písmenem ajin, „nahar“ (řeka) začínající písmenem „nun“ a „gan“ (zahrada) začínající písmenem „gimel“. Tato interpretace vychází z textu Berešit 2,10. (Rabejnu Bachja 20,8)

Radost v sobotu přináší rovněž účast na synagogální liturgii. V sobotu se obec schází v synagoze upevnit svůj vztah k Bohu i vzájemné vztahy svých členů. Bohoslužby

XLinguae, Volume 15 Issue 1, January 2022, ISSN 1337-8384, eISSN 2453-711X 
jsou běžně maariv (večerní bohoslužba), šacharit (ranní bohoslužba) a mincha (odpolední bohoslužba). Uvedené tři bohoslužby zpřítomňují tři podivuhodné a zcela jedinečné „události“, které již v minulosti proběhly, nebyly však ukončeny, stále v prrítomnosti probíhají a zároveň jsou neustále očekávány. Těmito „událostmi““ je: stvoření (připomínané Tefilou v pátek večer), zjevení (zdůrazněné Tefilou v sobotu ráno - šacharit a čtením Tóry) (Blažek, 2009: 306) a vykoupení (zdůrazněné Tefilou při sobotní bohoslužbě mincha). Tři základní synagogální bohoslužby také připomínají (dobou svého konání) chrámové oběti v Jeruzalémě. Podle rabi Jose ben Chaniny je zavedení každé z nich připisováno jednomu z praotců - večerní modlitba je spojena s Jaakovem, ranní s Avrahamem a odpolední s Jicchakem. (BT, Berachot 26b; srv. JT Berachot 4) Tři každodenní bohoslužby jsou v sobotu obohaceny pijuty, žalmy, verši Tóry a navíc je k nim přidána doplňková čtvrtá bohoslužba musaf. Sobotní bohoslužby jsou tak delší než bohoslužby ve všední dny. Sobota je vyhrazena Bohu, a proto je i čas věnovaný bohoslužbě delší. Výjimečně jsou některé části všednodenních bohoslužeb zkráceny. Sobotní Amida např́iklad obsahuje jen sedm a nikoliv osmnáct odstavců.

Určité části bohoslužby se vyskytují zároveň jako součást domácího obřadu, který se koná po návratu ze synagogy. Zda tyto obřady byly konány původně doma nebo v synagoze je nejasné. Zpravidla se předpokládá, že některé $\mathrm{z}$ domácích obřadů byly přeneseny do synagogy pro poutníky (jejichž rodina byla daleko), osamělé (kteří neměli rodinu) a chudé (kteří neměli dostatek finančních prostředků např́iklad na nákup vína a potravin).

\section{Vztah šabatu a Tóry}

Židovská filosofie člověka vnímá osobu jako jednotu těla a duše. Tuto jednotu promítá i do obrazu šabatu, který není jen časem na regeneraci tělesných sil a dnem odpočinku. Je to také den, ve kterém se člověk setkává $\mathrm{s}$ Bohem, prožívá s ním jednotu a stává se moudřejším. Výše jsme uvedli, že šabat je součástí pedagogického působení Hospodinova. Cílem svatého dne není jenom to, že se věřící klaní Bohu, cílem je také to, že hlouběji a lépe chápou, jaký to má pro ně význam. Stávají se moudřejšími. Na počátku respektují šabat proto, že je k tomu vedou rodiče. Později proto, že se bojí trestu a nakonec proto, že chtějí. Chápou význam tohoto svatého dne pro ně a pro své rodiny. Už se nemusí skrývat za strach a trest. Jejich svoboda se naplno rozvinula a oni ve svém nitru touží po tom, co od nich Bůh žádá. V tomto smyslu plného rozvinutí náboženské svobody je šabat propojen s dalšími nástroji výchovy.

Člověk, který dodržuje šabat, bude odměněn stejně jako ten, kdo dodržuje Tóru a dává desátky. (BT, Šabat 119a; Pesikta raba 23) Tóra (Učení) je ,jádrem všseho duchovniho kosmu, jehož vrstvy se k ni chovaji jako ke středu, jako obíhajíci planety ke Slunci. Vše je v ní obsaženo a vše z ní vyzařuje. " (Wiener, 1967: 78) Podle rabiho Akiby a Ravy (k nimž se přiklání většina rabínů) byla Tóra dána Izraeli v sobotu. (BT, Šabat 86a,b; Ejn Jaakov, Šabat 9,5; Rabejnu Bachja, Šemot 19.2.2) Rabi Jose se domníval, že týden pod horou Sinaj probíhal následovně: První den, tj. v neděli nebyla vydána žádná přikázání, protože lid byl unaven $\mathrm{z}$ namáhavé cesty $\mathrm{k}$ hoře. V úterý dostali př́kaz: „Budete mi královstvím kněži, pronárodem svatým. “ (Šemot 19,6). Ve stř̌edu byli varováni, aby se nepřibližovali k hoře. Ve čtvrtek dostali př́íkaz, aby se muži nepřibližovali ke svým ženám až do soboty. (Ejn Jaakov, Šabat 9,5) A v sobotu byla Izraeli dána Tóra a tento den se stal dnem jejího intenzivního studia.

Šabat otevřel Tóru všem a stal se tak „ručitelem toho, že Tóra nezůstala výsadou nepatrné skupiny učenců, nestala se pouhým predmětem bádání a sporů znalců Zákona, naopak stala se skutečným vlastnictvím všeho lidu, každý se měl Tórou zabývat. Šabat je den bez práce - určený pro práci nad Tórou. "(Wiener, 1967: 79) Šabat dává člověku čas věnovat se Tóře, učit se jí nazpamět', odhalovat její tajemství, učit jí své děti a hlavně žít s ní. 
Spjatost šabatu s Tórou nezbytně znamená, že tento den (více než jiné dny týdne) je úzce spjat se svatým jazykem - požehnání, modlitby, žalmy, chvály, vyznání víry, vzdávání díků, písně, čtení textu Tóry (Učení) a Neviim (Proroků), studium - to vše se koná v hebrejštině. V jazyce jehož prostřednictvím Bůh stvořil svět (protože hebrejsky řekl a stalo se). V jazyce, kterým stále komunikuje s vyvoleným lidem a zaslibuje naději nejen židovskému národu, ale i všem lidem.

V sobotu se židovská domácnost schází ke společnému studiu (toto studium však nesmí být namáhavé, mělo by přinášet radost), (BT, Šabat 12a) k modlitbám, písním, rozhovorům a ke slavnostnímu jídlu. To vše upevňuje jejich vztah k Bohu i vztahy uvnitř rodiny. Sobota tímto způsobem formuje rodinu jako základ vyvoleného lidu. V rodině jsou střeženy a předávány staré tradice předků, aby zůstaly stále živé pro budoucí generace. Každá rodina je tak zodpovědná za zachování duchovního charakteru vyvoleného lidu - Izraele. (Wiener, 1967: 80). Šabat se vším, co jej provází, není nostalgickou vzpomínkou na dobu předkủ. Není odleskem dávných dob. Naopak je stále živou a životodárnou studnicí, která svým těsným sepjetím s Tórou umožňuje stálou existenci Božího lidu.

Židé, jsou-li Božími vyznavači a svědky, se neustále těší na další a další šabat, který jim vytváří nekonečný prostor pro jejich nikdy nekončící studium. Z tohoto studia není nikdo vyloučen - muži, ženy, děti, sloužící i hosté - všichni jsou k němu radostně zváni. Studium bude pokračovat i v nebeské ješivě: „Vypravuje se, jak jistý rabín vystoupil ve snu na nebesa. Dostal svoleni přibližit se ke svatyni v ráji, kde velci talmudští učenci, tanaité, žiji své věčné životy. Viděl, že sedi kolem stolì a studuji Talmud. Rabín byl zklamán. ,A to je všechno, celý ráj?' zvolal překvapeně. Vtom uslyšel hlas: ,Mýlíš se, tanaité nejsou v ráji, to ráj je v nich"“ (Heschel , 2009: 56).

V současné době se někteří Židé domnívají, že je třeba učinit ústupky v dodržování sobotních prŕíkazů a zákazů. Domnívají se, že je například nezbytné povolit jízdu autem v sobotu (ale rozhodně jen na cestu do synagogy), opustit hebrejštinu (mimo území státu Jisrael), vzdát se víry ve vzkř́šení, opustit zázraky a vše, co nezapadá do vědeckého chápání světa.

Domnívají se, že je to cesta, která prrivede do synagogy více mladých lidí. Tyto ústupky však víru mladých lidí nezachrání. Je to však bezpečná cesta, jak jejich děti a vnuky od víry postupně odvést.

\section{5 Šabat jako micva}

Filosofie výchovy se odráží i v chápání šabatu jako př́kazu (hebr. micva). Není to jen forma zákazu činností či prŕíkazu oslavy Boha. Aplikace šabatu vnímaného jako micva vede k poznání a pochopení toho, že situace člověka má existenciální charakter. (Pavlíková, 2019). Člověk sám, bez pomoci Boha, nedokáže uspokojit své životní potřeby, byt' by pracoval i v den šabatu. A naopak, bude-li trávit šabat $\mathrm{s}$ Bohem a spolehne se na něj, dostane vše, co potřebuje. Svoboda je pak založena na spolehnutí se na Boha, na osvobození vlastní existence od svázanosti se světem a jeho povinnostmi. Bůh vytváří pomocí šabatu prostor pro lidskou svobodu, ve které je rozvíjí duchovní rozměr existence věřícího člověka.

Boží př́kaz („micva“) (Vymětalová - Hrabáková, 2014: 39 - 49) spojený se šabatem je formulován jako zákaz - nekonat zakázané druhy práce. (Mišna, Šabat 7,2; RAŠBA, BT, Jevamot 6a) Zároveň však má tato micva také pozitivní rozměr, protože přikazuje Hospodinovu vyznavači, aby si od práce odpočinul. (RAMBAN, Vajikra $23,24)$ Negativní micva (zákaz) se tak v tomto př́padě spojuje s pozitivní micvou (prríkaz), aby člověka dovedly ke stejnému cíli. Dodržovat šabat znamená přestat se spoléhat na sebe, na své síly a schopnosti a plně se spolehnout pouze na Boha.

Dodržování šabatu je „micva“ (př́kaz), kterou musí plnit všichni - muži, ženy i děti. (Kaf hachajim 261,16) Znesvěcení šabatu je z uvedeného důvodu popřením celé Tóry. (BT, Chulin 5a; Chajej adam, Hilchot šabat 1,1; Kicur šulchan aruch 72,1) Toto pojetí

XLinguae, Volume 15 Issue 1, January 2022, ISSN 1337-8384, eISSN 2453-711X 
je podle rabínské interpretace zakotveno již v Torat Moše, kde je zaznamenáno, že Bůh přikázal vyvolenému lidu na poušti sbírat šest dní manu (viz výše) a zároveň mu zakázal vycházet a sbírat v sobotu. (Šemot 16,31; Šemot 16,1-30) I přesto, že Bůh lidu oznámil, že v sobotu nebude nic padat, vycházel lid a hledal manu (Šemot 16,27). Toto porušení šabatu je Bohem charakterizováno jako porušení „micvotaj“ (mých př́kazů) a „torotaj“ (mých učení), (Šemot 16,28) což je později rabíny interpretováno jako porušení celé Tóry (viz výše).

\section{Závěr}

Šabat (sedmý den týdne) je zvláštním den. (Midraš raba, Šemot 25,16) Je to Bohem stanovený termín (hebr. „moed“) a hlavní mezník v uspořádání času. (Šemot 20,9-10 a) Trvalé znamení (hebr. „ot“) věčné smlouvy mezi Bohem a vyvoleným lidem (obdobně jako obřízka a tefilin). (Berešit 17,7.11; Šemot 31,13; BT, Sanhedrin 65a; Berešit raba 11; Pesikta rababati 23; Kicur šulchan aruch 72,1) Den úplného „oddání duše Bohu, vzepětí emocí k nekonečnu. (Wiener, 1967: 75) Bůh se v tento den ve svém neskonalém milosrdenství zvláštním způsobem sklání k člověku. Člověk ustává ve svém šestidenní lopotě a získává čas pro setkání s ním. Dodržování a nedodržování šabatu rozhoduje o požehnání a prokletí člověka. (Vajikra 26; Jirmejahu 17,21-27; Ješajahu 56,2-7; 58,13-14; Nechemja 13,17-18) Kdo zachovává šabat je odměněn nejen v tomto světě, ale získává velkou zásluhu také pro svět budoucí. (Kicur šulchan aruch 72,3) Šabat posiluje víru jednotlivce i společenství a zároveň je viditelným vyznáním víry Izraele. Šabat je ,,duchovní vrchol týdne... den, který by měl dominovat našemu myšlení po celý týden, protože je to nejdi̊ležitějši den" (Chizkuni, Šemot 20,8.). Šabat přináší požehnání pro všechny následující dny týdne. (Zohar II,88) Přináší odpočinutí, posvěcení, potěšení a vážnost jednotlivci i celému společenství.

Sobota (na rozdíl od ,jamim noraim“) není dnem vzbuzujícím bázeň, není to těžké jho, které Izrael na sebe prijal, ale je to den radosti, na který se věřící Židé celý týden těší. (Ješajahu 58,13-14) Již proroci varovali před netrpělivým očekáváním jejího konce. (Amos 8,5; Ejcha 2,6) Zákaz slavení šabatu byl chápán jako trest. (Hošea 1,13) V současné době se Židé běžně rozdělují podle toho, zda se hlásí k ortodoxní, konzervativní či reformované obci. Ve vztahu k našemu tématu však můžeme, řičí, že existují pouze dva druhy Židů, ti kteří zachovávají sobotu a ti, kteří ji porušují. Jedni udržují řád Bohem stvořeného světa a participují na jeho věčném řádu. Druzí jej ničí a vrhají stvoření zpět do původního prastavu pustoty a prázdnoty. (Simkins, 1994: 198)

\section{Acknowledgement}

This article was published with the support of International Scientific Research Project: Pastoral practice, psychology and philosophical-theological-social fragments in the light of the 21st century (contract number: 010-2021). Cooperation among: Sociedad Hispánica de Amigos de Kierkegaard (Spain) and College of Applied Psychology in Terezín (Czech Republic), 2021-2022.

\section{Bibliographic references}

Arama, I. ben Moses. (2001). Akedat Yitzchak. Commentary of Rabbi Yitzchak Arama. I., II., Rubin Mass. 2001.

Avraham, D. (2009). Sifs(t)ei Chachamim Chumash. Shemos. Metsudah Publications. ISBN: 78. 410000188.

Bible, Písmo svaté Starého a Nového zákona. 1985. Ekumenický překlad. 2. vyd. Praha: Biblická společnost v ČSR 1985.

Biblia Hebraica Stuttgartensia. (1990). Elliger, K., Rudolph, W. 4. vyd. Stuttgart: Deutsche Bibelgesellschaft 1990. ISBN 3-438-05219-9.

Blazek, J., Holubova, M. (2009). Sidur Adir ba-marom. Modlitební kniha pro všední dny, šabat a svátky s paralelním českým překladem a komentářem. Praha: Bergman, 2009. 
Foundations of the Tórah. Moznaim Pub Corp., 1989. ISBN: 9780940118416.

Divecky, J. (2005). Židovské svátky. Kalendářem od Pesachu do Purimu. Praha: Nakladatelství P3K.

Ganzfried, S. (2012). Kicur šulchan aruch. I., II., Těšín: Agadah, 2012. ISBN: 978-8087571-01-9.

Ginzberg, L. (1998). The Legends of the Jews. III. Moses in the Widerness. The John's Hopkins University Press, Baltimore and London, 1998. ISBN: 0-8018-58925 .

Greenwald, Z. (2012). Ša'arej halacha. Brány halachy. Praktický souhrn tradičních halachických zákonů. Těšín: Agadah 2012. ISBN: 978-80-87571-02-6.

Heschel, J. A. (2009). Šabat. Jeho význam pro současného člověka. Praha: Academia, 2009. ISBN 978-80-200-1721-5.

Hewit, S. R. (2013). Welcoming Shabbat. A Guide To Lighting Shabbat Candles. New York. 1987.

Munk, E. ed. (2013). Chizkuni. Torah Commentary. Ktav Publishers: Jerusalem, 2013. ISBN 978-1-60280-261-2.

Kaplan, A. (1991). Anthology. II., New York 1991.

Kralik, R. (2013). The Reception of Soren Kierkegaard in Czech Language Writings. In: Filosoficky casopis, vol. 61, n. 3, pp. 443-451. ISSN 0015-1831.

Kralik, R. (2016). Slovakia: A joint project of two generations. Volume 8, Tome II: Kierkegaard's International Reception - Southern, Central and Eastern Europe, Routledge 2016, vol. 8, pp. 189-204.

Kralik, R., Pavlikova, M. (2013). The reception of Kierkegaard's work in Slovakia, In: Filozofia, vol. 68, n. 1, pp. 82-86, ISSN 0046-385X

Levi, I. Ben Meir of Berdichev, 1966/67. Sefer Kedushat Levi Al Ha-Torah uMo'adim. I., II. Mekhon Kedoshat Levi, Brooklyn - New York 1996/97.

Machon $\mathrm{Da}^{\prime}$ at J. (1994). Sefer Mišna berura ve-hu peruš jqfe u-menupe al Šulchan aruch Orach chajim. Zv.3. 1994.

Munk, E. ed. (2003). Midrash Rabbeinu Bachya. Torah Commentary by Rabbi Bachya ben Asher. Lambda Publishers: Jerusalem, 2003. ISBN 965-7108-45-4.

Neusner, J. ed. (1988). Mekhilta According to Rabbi Ishmael. Scholars Press: Atlanta, 1988. ISBN 1-55540-237-2.

Pavlikova, M. (2019). Existential features of Søren Kierkegaard in modern American Literature. Toronto: Kierkegaard Circle, University of Toronto, 2019. 64. p. ISBN 978-1-988129-05-1.

Pelcovitz, R. (1997). Sforno. Commentary on the Torah. Mesorah Publications: Brooklyn, 1997. ISBN 0-89906-268-7.

Rabin, E. (1967). Jüdisches Fest, Jüdischer Brauch. Berlin: Jüdischer Verlag, 1967.

Rabinovitch, M. ed. (2006). The Mishnah. New York: Mesorah Publications, Ltd. 2006.

Rambam (Maimon ben Moše) (1989). Mishneh Tórah, Hilchot Yesodei HaTórah. The Laws, Which Are the

Sacks, J. (2013). O svobodě a náboženství. Praha: P3K, 2013. ISBN 978-80-8734319-7.

Simkins, R. A. (1994). Creator and Creation. Massachusetts: Hendrickson Publishers, 1994.

Sperling, H. (1984). Zohar. New York: Soncino, 1984.

Talmud Bavli. 1997. The Schottenstein Daf Yomi Edition. New York: Menorah Publications, Ltd. 1997.

The commentators'Bible, the JPS Miqraot gedolot. (2005). Edited, translated and annotated by Michael Carasik, Philadelphia, Jewish Publication Society, 2005.

Theoor, J., Albeck, Ch. (1965). Midrash Bereshit Rabba. Critical Edition with Notes and Commentary. Jerusalem, 1965.

XLinguae, Volume 15 Issue 1, January 2022, ISSN 1337-8384, eISSN 2453-711X 
The Pentateuch and Rashi's Commentary. 1977. Abraham ben Isaiah, Benjamin Sharfman, Brooklyn, Publishing Company, 1977.

Vymetalova-Hrabakova, E. (2014). Noachické prŕkazy v minulosti i dnes optikou křest’anské etiky. In: Veverková, K., Bible a etika v kontextu doby a myšlení, Praha: L. Marek 2014.

Wiener, M. (2014). Der Sabbat. In: RABIN, E., Jüdisches Fest, Jüdischer Brauch. Berlin: Jüdischer Verlag, 1967.

Wistinetzki, J. (ed.) 1924. Sefer chasidim. Frankfurt am Main, 1924.

Zalec, B, Pavlikova, M. (2019). Religious tolerance and intolerance. In: European Journal of Science and Theology, vol. 15, n. 5, pp. 39-48.

Internet Sources:

Babylonsky talmud (BT), Available online: http://www.mechonmamre.org/b/1/10.htm Visited: [12.09.2021]

Ezra's Torah Commentary, Available online: http://mg.alhatorah.org/Dual/Ibn_Ezra_First_Commentary/1.1\#t1e0n6 Visited: [12.09.2021]

Jeruzalemsky talmud (JT), Available online: http://www.mechonmamre.org/b/r/r0.htm Visited: [12.09.2021]

Lubliner, L. (2012). Recreational Sports and Exercise on Shabbat. [online] Available: https://www.rabbinicalassembly.org/story/home-observances-shabbat Visited: [12.09.2021]

Misna, Available online: http://www.mechon-mamre.org/b/h/h0.htm Ramban: https://www.artscroll.com/Categories/rbn.html Visited: [12.09.2021]

Rashi's Torah Commentary, http://alhatorah.org/Commentators:Rashi_Leipzig_ Misne Tora, Available online: http://www.mechonmamre.org/i/0.htm Visited: [12.09.2021]

Tosefta, Available online: http://www.mechon-mamre.org/b/f/f0.htm Visited: [12.09.2021]

\section{Words: 6145}

Characters:40 858 (22,70 standard pages)

ThDr. Marie Roubalova, ThD.

Hussite Theological Faculty Charles University in Prague

Pacovská 350/4, 14000 Praha

Czech Republic

marie.roubalova@htf.cuni.cz

Assoc. Prof. ThDr. Patrik Maturkanic, PhD. (corresponding author)

College of Applied Psychology

Akademická 409, 41155 Terezín

Czech Republic

maturkanic@vsaps.cz

Assoc. Prof. PhDr. Janka Bursova, PhDr., MBA

Faculty of Theology

The Catholic University in Ružomberok

Hrabovská cesta 1A, 03401 Ružomberok

Slovak Republic

janka.bursova@ku.sk

Assoc. Prof. PhDr. Peter Kondrla, PhD.

Faculty of Arts

Constantine the Philosopher University in Nitra 
Tr. A. Hlinku 1, 94901 Nitra

Slovak Republic

pkondrla@ukf.sk

Prof. dr hab. Jan Zimny, PhD.

Akademia Wojsk Lądowych imienia generała Tadeusza Kościuszki we Wrocławiu

General Tadeusz Kościuszko Military University of Land Forces in Wrocław PL

Ul. Czajkowskiego 106

51-147 Wrocław

Poland

jzimny@przemysl.opoka.org.pl 